\title{
Evaluation of the ecological status of an impaired watershed by using a multi-index approach
}

\author{
Liliana Carvalho $\cdot$ Rui Cortes • \\ Adriano A. Bordalo
}

Received: 26 November 2008 / Accepted: 7 April 2010 / Published online: 7 May 2010

(C) Springer Science+Business Media B.V. 2010

\begin{abstract}
The objective of this study was to use an integrative approach to assess the ecological status of a small river impacted by multiple sources of disturbance. The River Febros (NW Portugal) is a small and highly impacted non-regulated river; approximately $44 \%$ of the watershed area is dedicated to agriculture, but there is also some urbanization. Environmental status was evaluated using a new multi-index approach, combining quality indices for water (Water Quality Index (WQI)), benthic macroinvertebrates (Iberian Biological Monitoring Working Party Index (IBMWP)), and human modification (Riparian Forest Quality Index (QBR)); Ecological Status River Mediterranean Index (ECOSTRIMED); River Habitat Survey (RHS)). Surveys were car-
\end{abstract}

L. Carvalho $(\bowtie) \cdot$ A. A. Bordalo

Laboratory of Hydrobiology, Institute of Biomedical

Sciences (ICBAS), University of Porto,

Lg. Professor Abel Salazar, 2,

4099-003 Porto, Portugal

e-mail: lqacarvalho@gmail.com

R. Cortes

Florestal Department, University of Trás-os-Montes e Alto Douro (UTAD), Apartado 1013,

5001-911 Vila Real Codex, Portugal

A. A. Bordalo

CIIMAR/CIMAR - Center for Interdisciplinary

Environmental and Marine Research,

Rua dos Bragas, 289, 4050-123 Porto, Portugal ried out between October 2002 and 2003, along four stretches of the main course of the river for physicochemical characteristics, as well as water microbiology and macroinvertebrates. Water quality was poor at all sites (WQI averaged $30.4 \%$ ) and decreased downstream. The RHS (assessment of instream habitats and the river corridor) and the QBR quantification displayed the same trend. Macroinvertebrates diversity was permanently low with only the most tolerant insects taxa present; oligochaetes dominated. The ecological status of River Febros was well represented using the experimental assessment system, where a downstream decrease in condition was noticeable (in spite of a lower water quality upstream). Our results emphasize the importance of assessing several components of disturbed ecosystems in order to ascertain overall quality and the importance of promoting improvement of the riparian gallery as a buffer against multiple agents of disturbance.

Keywords WQI • IBMWP • RHS • QBR •

Scaled values $\cdot$ River Febros

\section{Introduction}

Reliable detection of human impacts on river systems is challenging due to the diversity of biological, chemical, hydrological, and geophysical 
components that must be assessed (Gergel et al. 2002). Modifications in land use change comprise one of the most universal anthropogenic influences on global ecosystems (Dale et al. 2000). Degradation of freshwaters results from the increasing inputs of silt, nutrients, and pollutants resulting from agriculture, forest harvest, urban areas (Carpenter et al. 1998; Maddock 1999; Palmer et al. 2002), and industry (Azrina et al. 2006; Mokaya et al. 2004; Paul and Meyer 2001). These impacts reduce both water quality (Sweeting 1994) and biological diversity of aquatic ecosystems (Maddock 1999).

Lotic ecosystems have lateral (channelriparian zone-floodplain); longitudinal (a lowerorder stream to a higher-order stream, upstream to downstream) and vertical (atmosphericsurface-groundwater interactions) relationships with the surrounding environment. The relative importance of these relationships varies both spatially and temporally (Novotny et al. 2005). The key components of watershed management focus on identifying and pinpointing factors that impair system integrity followed by the development and implementation of remedial measures (Rogers et al. 2002).

The evaluation of the ecological impacts on urban streams, which are subject to both chemical and physical degradation, can be very difficult to assess, because the effects of contaminants may be masked by comparable or larger influences such as stream canalization, clearance of riparian vegetation, or other physical stressors (Rogers et al. 2002). In spite of significant progress made in controlling point sources of water pollution (domestic sewage or industrial effluents, for instance), nonpoint pollution (runoff from agriculture, urban, mining, and livestock areas) is still a recurrent problem in many watersheds (Mainstone and Parr 2002; Williams et al. 1997). Within the watershed, human activities result in higher surface runoff, the rate of which is influenced by land use, vegetation cover, and landscape mosaic (Geraldes and Boavida 2003). Increased runoff often results in eutrophication ultimately threatening water quality (Allan et al. 1997; Mokaya et al. 2004).

Lotic system monitoring methods often compare pristine or near natural sites (i.e., reference conditions) with reaches over a gradient of perturbation. The reference condition approach is inherent to the Water Framework Directive (WFD, EC 2000), however, we ask how this can be possible when an entire river system is affected by intensive human pressures and reference sites are virtually absent. According to Reynoldson et al. (1997), some aspects of reference conditions can be established based upon best professional judgment, avoiding the need for comparisons with specific reference sites. However, if no reference sites are available, a common situation in highly urbanized areas or heavily agricultural regions, reference conditions can be selected from across an entire population of sites. This approach was developed, for example by Karr et al. (1986) for the Index of Biotic Integrity (IBI). According to Chovanec et al. (2000), reference conditions must be theoretically constructed by combining historical data (e.g., old maps or long-term biological records) and models.

The execution of rehabilitation measures on a highly impacted and/or modified watershed is questionable, concerning management purposes. Restoration techniques are often directed towards the reestablishment of natural physical environment, including the riparian gallery (Harper et al. 1999; Naiman and Décamps 1997; Piégay and Landon 1997). Many authors have demonstrated significant improvements in water quality and aquatic communities (Lazdinis and Angelstam 2005; Thoms and Sheldon 2000; Vought et al. 1995), achieved following rehabilitation of riparian ecotones (Mander et al. 1995; Robertson and Rowling 2000; Vought et al. 1995). The management of highly disturbed water bodies compromises numerous factors, including changes in water quality and quantity, hydrology, hydraulics, and habitat. This is especially true for urban watersheds which are subject to the greatest pressures (Baer and Pringle 2000; Brown 2005; Naiman et al. 1995), as a result of several processes that occur at different spatial scales (Allan et al. 1997). According to Maddock (1999), more holistic assessment indices should be created through improved multidisciplinary concepts that address all aspects of the environment simultaneously (Brown 2005).

There is a need to define monitoring and restoration rules for highly impaired rivers. This 
study was conducted in a highly disturbed but non-regulated river, River Febros, located in NW Portugal. This study aimed (1) to define an integrative methodology for the ecological characterization of a highly impacted river; (2) to study its temporal and spatial dynamism; and (3) to establish links between the physical habitat, water quality, and aquatic communities, using the benthic fauna as a proxy, through the application of multiple indices. This provides a pilot study for numerous streams along the European Atlantic Coast enabling water and sediment quality characterization, the classification of the riparian zones, and assessment of the riverine biological condition.

\section{Materials and methods}

\section{Study area}

The River Febros watershed has a south-north orientation and covers an area of $35.4 \mathrm{Km}^{2}$. The river, which crosses slate zones, has a total main course length of $15.3 \mathrm{Km}$ (Fig. 1). The Febros river runs from Seixezelo $\left(41.03^{\circ} \mathrm{N} / 8.56^{\circ} \mathrm{W}\right)$ to Esteiro $\left(41.12^{\circ} \mathrm{N} / 8.57^{\circ} \mathrm{W}\right)$. The Febros valley has specific characteristics; the left river bank is steeper than the right one (average altitude $\approx 77.2 \mathrm{~m}$, ranging between 0 and $250 \mathrm{~m})$. The compacity index $\left(K_{\mathrm{c}}\right.$, defined as the ratio of basin perimeter to the
Table 1 Percentage of land use in the surrounding area $(\phi=1 \mathrm{Km})$ of each sampling station of river Febros

\begin{tabular}{lllll}
\hline $\begin{array}{l}\text { Sampling } \\
\text { station }\end{array}$ & $\begin{array}{l}\text { Forest } \\
(\%)\end{array}$ & $\begin{array}{l}\text { Industry } \\
(\%)\end{array}$ & $\begin{array}{l}\text { Housing } \\
(\%)\end{array}$ & $\begin{array}{l}\text { Agriculture } \\
(\%)\end{array}$ \\
\hline 1 & 21.1 & 0.6 & 14.1 & 64.2 \\
2 & 28.7 & 1.3 & 30.7 & 39.4 \\
3 & 61.8 & 1.9 & 10.0 & 26.3 \\
4 & 68.7 & 2.4 & 8.6 & 20.4 \\
\hline
\end{tabular}

circumference of a circle with area equal to that of the basin) is 1.32 , the shape factor $\left(K_{\mathrm{f}}\right)$ is 0.15 , and its draining density $(\lambda)$ is $1.043 \mathrm{Km} \mathrm{Km}^{-2}$. The river crosses areas of high populational density along its course (total population $\approx 63,000$ habitants), as well as industrial and agricultural areas. Agriculture is the main type of land use within the watershed $(44.1 \%)$, followed by forestry $(35.9 \%)$, housing $(16.3 \%)$, and industry $(3.7 \%)$. Four sampling stations were established along the main river channel (Fig. 1), including the river mouth and three other zones earmarked for possible future ecological restoration. The four stations were chosen following a preliminary survey that characterized 12 potential zones within the main course of the river (data not shown). In the two downstream stations, land use was essentially urban/agriculture, whereas upstream land use was dominated by intensive forestation (Table 1). The percentages of land use in the surrounding area of $1 \mathrm{Km}$ diameter from each sampling station were calculated from 2002 aerial photographs.
Fig. 1 Identification of the river Febros watershed, location of sampling stations (distance from mouth: $10.1 \mathrm{Km} ; 21.6 \mathrm{Km}$; $39.7 \mathrm{Km}$, and $411.1 \mathrm{Km}$ ) and Febros Waste Water Treatment Plant

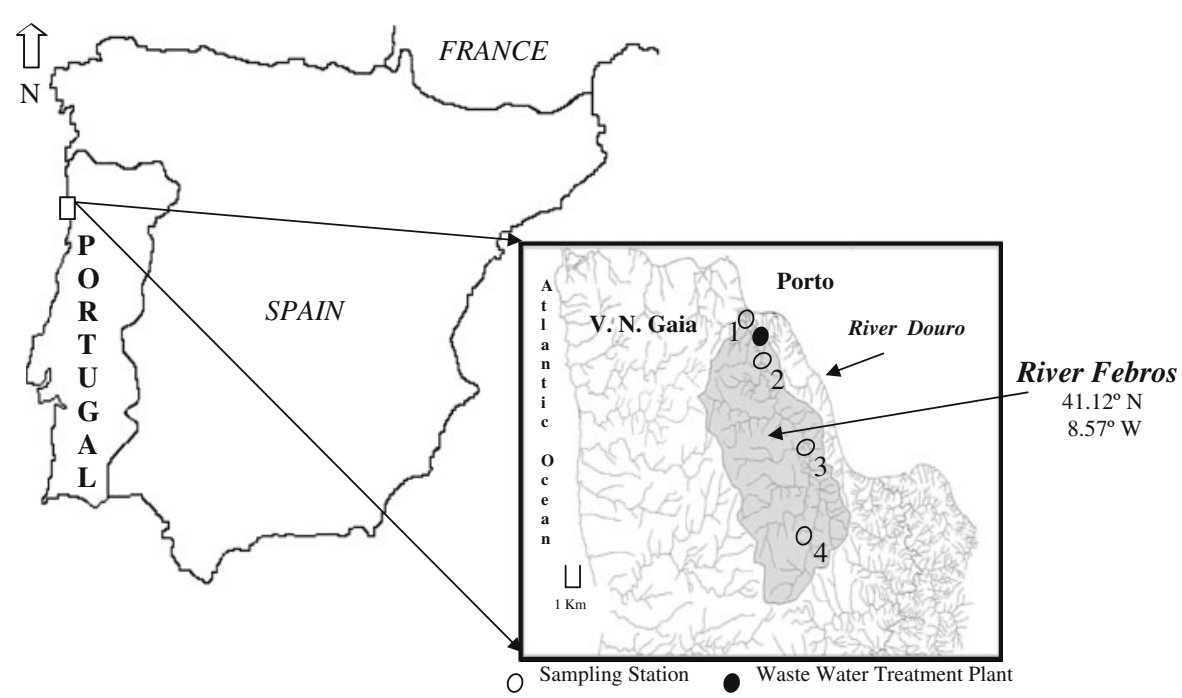


The location of the Febros Waste Water Treatment Plant (WWTP), which was dimensioned for a population of 80,000 inhabitants and an inflow of $14,000 \mathrm{~m}^{3} \mathrm{day}^{-1}$, is shown on Fig. 1.

All sampling stations were geo-referenced using a GPS (Magellan 315). Samples of water and sediment (percentage of organic matter, grain size, and macroinvertebrates) were collected every 2 months between October 2002 and October 2003 .

\section{Water quality}

Temperature, conductivity, total dissolved solids, dissolved oxygen and saturation, $\mathrm{pH}$ and oxyreduction potential were measured in situ with a multiparametric probe (YSI $600 \mathrm{XL}$ ). Water samples were collected by immersing glass (for bacteria) and plastic bottles (for the chemical nutrients and chlorophyll $a$ ) with the bottle mouth facing against the current to minimize contamination from the operator. Discharge $(Q)$ was calculated by the formula $Q=\operatorname{Velocity}(V) \times \operatorname{Section}(A)$.

Dissolved orthophosphate, nitrite, and ammonium were analyzed following the methods described in Grasshoff et al. (1983). Nitrate was quantified by an adaptation of the spongy cadmium reduction technique (Jones 1984), subtracting nitrite value from the total. All analyses were performed in triplicate. Chlorophyll $a$ was assayed spectrophotometrically after extraction with 90\% acetone (Parsons et al. 1984) with cell homogenization, using the SCOR-UNESCO (1966) trichromatic equation. The chemical oxygen demand (COD) was performed in a thermo-reactor (Merck TR320) and a photometer (SPECTROQUANT 118), and the $\mathrm{BOD}_{5}$ (Biochemical Oxygen Demand) was assayed using a modified Winkler method (Carpenter 1965; Carritt and Carpenter 1966). Turbidity values were measured in a photometer (C114, Hanna Instruments). Fecal coliforms (FC) were assayed on mFC agar (Difco 0677-17) following a 24-h incubation at $44.4 \pm 0.1^{\circ} \mathrm{C}$ and heterotrophic bacteria on nutrient agar (Oxoid CM19) after a 7-day incubation period at room temperature (Bordalo 1993).

A modified version of the Scottish water quality index (WQI; SDD 1976) was used to assess water quality, adapted to temperate and tropical environments (Bordalo et al. 2001, 2006). We used the original SDD version adapted to temperate environments with a reduced number of parameters (nine parameters compared to 10). The used WQI aggregates physical parameters (temperature, conductivity, suspended solids), chemical parameters $(\mathrm{pH}$, ammonium, dissolved oxygen), and organic/microbiological parameters (fecal coliforms, biological oxygen demand, chemical oxygen demand; Bordalo et al. 2006). We used the weighted arithmetic average to aggregate sub-indices since it is particularly suitable for the indexation of the general water quality (House 1989). The scaled weighting value attributed to each individual parameter for WQIs calculation is presented in Table 2. The modified index is obtained from the water quality ratings $\left(q_{i}\right)$ and weight of each individual parameter $\left(w_{i}\right)$, according to Eq. 1 (Bordalo et al. 2006). The range of derived values is from $0 \%$ (the poorest) to $100 \%$ (the highest) water quality (SDD 1976). For the present study, the House and Ellis (1987) class rating was adopted: $10-25 \%$ badly polluted; $26-$ $50 \%$ polluted; $51-70 \%$ reasonable; $71-90 \%$ good; and $91-100 \%$ very good.

$\mathrm{WQI}=1 / 100\left(\sum_{i=1}^{9} q \mathrm{i} w i\right) 2$

where,

$q_{i} \quad$ water quality ratings

$w_{i} \quad$ weight of each individual parameter

Table 2 Scaled individual weighting $\left(w_{i}\right)$ attributed to each water parameter for the calculation of the WQIs

\begin{tabular}{lll}
\hline Parameter & & $\begin{array}{l}\text { Scaled individual } \\
\text { weighting }\left(w_{i}\right)\end{array}$ \\
\hline Physical & Temperature & 0.05 \\
& Conductivity & 0.06 \\
& Suspended solids & 0.07 \\
Chemical & pH & 0.09 \\
& Ammonium & 0.12 \\
& Dissolved oxygen & 0.19 \\
Organic/ & Fecal coliforms & 0.12 \\
microbiological & Biological oxygen & 0.15 \\
& demand & \\
& Chemical oxygen & 0.15 \\
& demand & \\
\hline
\end{tabular}


Sediment characterization

Sediments were retrieved by hand in the shallow stretches of the river. Unfixed sediments were treated in order to determine the percentage of organic matter, by drying the samples at $105^{\circ} \mathrm{C}$ $(24 \mathrm{~h})$ and then by loss on ignition at $500^{\circ} \mathrm{C}$ (4 h; APHA 1992). Grain size was estimated by sieving the samples and dividing the sediment into seven fractions: silt and clay $(<0.063 \mathrm{~mm})$, very fine sand $(0.063-0.125 \mathrm{~mm})$, fine sand $(0.125-$ $0.250 \mathrm{~mm})$, medium sand $(0.250-0.5 \mathrm{~mm})$, coarse sand $(0.5-1 \mathrm{~mm})$, very coarse sand $(1-2 \mathrm{~mm})$, and gravel $(>2 \mathrm{~mm})$. Each fraction was weighed and expressed as a percentage of the total weight.

\section{Biological assessment}

A hand net $(40 \times 20 \mathrm{~cm}, 500 \mu \mathrm{m}$ mesh size $)$ was used to collect benthic macroinvertebrates, over a 3-min period using the kick procedure (Cortes et al. 2002). The volume of sediment captured was fixed, in situ, with formaldehyde and Bengal Rose solution (4\%) and placed in a hermetically closed bag. Once in the laboratory, the fixed sediment samples were washed with tap water and sieved (500 $\mu \mathrm{m}$ mesh size), in order to sort, count, and identify macroinvertebrates (Tachet et al. 1994). Identification to family level was performed using a stereomicroscope (Leica MZ12-5; magnification $\times 8-100)$. All macroinvertebrates were preserved in a solution of $70 \% v / v$ alcohol. Ecological quality was determined using the IBMWP index (Alba-Tercedor and Sánchez-Ortega 1988), which has been widely applied in the Iberian Peninsula and provides a value resulting from the sum of values attributed to key macroinvertebrate families according to their tolerance to organic pollution. Besides the inherent simplicity (Rico et al. 1992), it showed to be efficient in quantifying the organic enrichment. In order to overcome the inherent weakness of the IBMWP system, namely the direct influence of sampling effort, the Average Score per Taxa (ASPT) was calculated (Armitage et al. 1983). The Ephemeroptera, Plecoptera, Trichoptera Richness Index (EPT index) was also used (Barbour et al. 1999). The result obtained with this index is taken as an indicator of ecological quality and allows for between-site com- parisons. Low values (few EPT taxa) can indicate degraded water quality, while higher EPT taxa richness values indicate better water quality. Benthic macroinvertebrates diversity was calculated using the Shannon diversity index $\left(\mathrm{H}^{\prime}\right.$; Shannon and Weaver 1963), which is based on the information theory and refers to the specific richness and frequency distribution.

\section{River corridor and fluvial habitat}

The Riparian Forest Quality Index (QBR; Munné et al. 1998) was one of the indices used to evaluate the conservation state of the studied river, through the classification of the composition and structure of the riparian layer. The sum of the QBR component factors vary between 0 and 100 . We also used the Ecological Status River Mediterranean (ECOSTRIMED) index (Prat et al. 2000) to evaluate the quality of the entire fluvial ecosystem (Table 3). ECOSTRIMED is a rapid water quality index (Rapid Bioassessment Protocol). For Mediterranean rivers, the ecological state is calculated by combining the values of one biological quality index based on macroinvertebrates (e.g., IBMWP) and the QBR.

An adaptation of the River Habitat Survey (RHSm) was used to obtain a detailed characterization of instream habitats and the river corridor (Raven et al. 1998). We used a modified Habitat Quality Assessment index (HQAm) and a modified Habitat Modification Score (HMSm). RHS provides a systematic framework for the collection and analysis of data associated with the physical structure of watercourses giving a broad measure of the diversity and "naturalness" of the habitat structure of a given site (Raven et al.

Table 3 Determination of the ecological state (ECOSTRIMED) through the combination of the values of the quality index IBMWP and the QBR index

\begin{tabular}{llll}
\hline IBMWP & QBR & & \\
\cline { 2 - 4 } & $>75$ & $45-75$ & $<45$ \\
\hline$>100$ & Very good & Good & Mediocre \\
$61-100$ & Good & Mediocre & Bad \\
$36-60$ & Mediocre & Bad & Very bad \\
$<36$ & Bad & Very bad & Very bad \\
\hline
\end{tabular}


1998). Field data is collected using a standard continuous observation along $500 \mathrm{~m}$ length of river channel (called sweep up) and by 10 transects (spot checks) separated by $50 \mathrm{~m}$. In this study, we carried out RHSm over a total segment length of only $50 \mathrm{~m}$ comprising five spot checks $10 \mathrm{~m}$ apart and sweep up along the total length of the reduced segment. The objective was to achieve a better relationship between the biological data and habitat descriptors since several authors have found a weak association between RHS and biological data mainly attributable to the different spatial scales of each type of analysis, i.e., biological data such as benthic fauna are obtained from sets of micro-habitats while RHS data derives from a larger scale of one or more meso-habitats (Cortes et al. 2008; Davenport et al. 2004; Tickner et al. 2000).

\section{Scaled values}

The values obtained from the WQI, IBMWP, ASPT, EPT, H', QBR, HMSm, and HQAm indices were used together in order to calculate a mean rank for each station. The ranks for each index were scaled in order to maximize the relative nature of the data among stations. HMSm values were ranked inversely to calculate the scaled value, since the values of this index decrease with increasing HQAm. All values, for a particular index, were scaled to a $0-10$ range using the following formula:

$\begin{aligned} \text { Scaled value }= & {[(\text { value }- \text { minimum })} \\ & /(\text { maximum }- \text { minimum })] \times 10\end{aligned}$

The mean of the scaled values was used in the ranking procedure to estimate the global state of each sampling station.

As with any ranking procedure, there is certain degree of subjectivity. However, this procedure was used to provide a valid way to integrate several indices providing a global characterization, compare sampling stations and analyze spatial trends.

\section{Data analysis}

Chemical and bacteriological analyses were performed in triplicate and duplicate, respectively, and the results averaged. Fecal coliform and heterotrophic bacteria data were log-transformed in order to stabilize the variance. Macroinvertebrates families data were $\log$-transformed $\left[\log _{10}\right.$ $(x+1)]$ in order to reduce the influence of abundant families. Temporal and spatial 2D-map of WQI was obtained with SURFER software, using kriging as the interpolation method. The RHS Database software, version 3.3 was used to calculate HQAm (and its sub-indices) and HMSm indices. Variation on environmental variables between stations and between seasons was assessed using analyses of variance ANOVA $(p<0.05)$, using STATISTICA 6.0. The Tukey HSD test was used a posteriori to determine which means were significantly different $(p<0.05)$. Environmental variables were examined using principal components analysis (PCA) and nonmetric multidimensional scaling (nMDS) ordination based on the Bray-Curtis similarity measure was performed to find temporal patterns in biological data (Bray and Curtis 1957). Multivariate analyses were performed with the software package Plymouth Routines Multivariate Ecological Research (PRIMER; Clarke and Warwick 1994).

\section{Results}

Water quality

The lower reaches of the river (station 1) showed higher conductivity, $\mathrm{pH}$, and nutrient values (Tukey MSD Test, $p<0.05$ ) and the lowest oxygen content (Table 4). Nitrate concentrations were particularly high (average $=$ $316.6 \pm 20.2 \mu \mathrm{M}$ ) and values $>600 \mu \mathrm{M}$ were common, especially near the river mouth (Table 4). Nitrite and ammonium values were also high. The sampling sites (stations 1 to 4 ) were all highly contaminated by sewage, fecal coliform values ranged from 3,000 to $983,000 \mathrm{cfu} 100 \mathrm{ml}^{-1}$ with no statistical differences between stations (Tukey MSD Test, $p>0.05$ ).

Temperature, dissolved oxygen, $\mathrm{BOD}_{5}$, and nitrate showed significant seasonal variability (ANOVA, $p<0.05$ ). The values obtained for the $\mathrm{BOD}_{5}$ and COD were especially high $(7.8 \pm 0.7$ and $144.8 \pm 62.1 \mathrm{mg} \mathrm{l}^{-1}$, respectively, Table 4), 
Table 4 Arithmetic mean, SE, minimum, maximum, and respective station and survey date for selected water parameters, between October 2002 and October 2003

\begin{tabular}{|c|c|c|c|c|c|c|c|c|}
\hline \multirow[t]{2}{*}{ Parameter } & \multirow[t]{2}{*}{ Mean } & \multirow[t]{2}{*}{$\mathrm{SE}$} & \multicolumn{3}{|c|}{ Minimum } & \multicolumn{3}{|c|}{ Maximum } \\
\hline & & & Value & Station & Date & Value & Station & Date \\
\hline Discharge $\left(\mathrm{m}^{3} \mathrm{~s}^{-1}\right)$ & 3.62 & 0.81 & 0.81 & 2 & 20.06 .03 & 6.35 & 2 & 30.12 .02 \\
\hline Cond. $\left(\mu \mathrm{S} \mathrm{cm}^{-1}\right)$ & 276.42 & 30.36 & 141.00 & 3 & 01.10 .03 & $1,502.00$ & 1 & 07.08 .03 \\
\hline Temp. $\left({ }^{\circ} \mathrm{C}\right)$ & 16.48 & 0.47 & 10.84 & 2 & 26.02 .03 & 25.29 & 2 & 20.06 .03 \\
\hline $\mathrm{pH}$ & 7.49 & 0.07 & 6.63 & 4 & 01.10 .03 & 9.40 & 1 & 15.07 .03 \\
\hline Turbidity (FTU) & 42.92 & 12.94 & 1.36 & 2 & 20.06 .03 & 330.00 & 3 & 30.10 .02 \\
\hline Oxy sat. (\%) & 104.83 & 1.25 & 91.20 & 1 & 01.10 .03 & 125.20 & 3 & 16.04 .03 \\
\hline $\mathrm{BOD}_{5}\left(\mathrm{mg} \mathrm{l}^{-1}\right)$ & 7.75 & 0.70 & 1.85 & 3 & 26.02 .03 & 14.68 & 4 & 27.08 .03 \\
\hline $\mathrm{COD}\left(\mathrm{mg} \mathrm{l}^{-1}\right)$ & 144.79 & 62.08 & 20.00 & 3 & 16.04 .03 & $1,480.00$ & 3 & 30.10 .02 \\
\hline Nitrate $(\mu \mathrm{M})$ & 316.55 & 20.20 & 112.89 & 3 & 30.10 .02 & 819.75 & 1 & 30.07 .03 \\
\hline Nitrite $(\mu \mathrm{M})$ & 5.40 & 0.59 & 0.56 & 3 & 07.08 .03 & 17.48 & 2 & 20.06 .03 \\
\hline Ammonium $(\mu \mathrm{M})$ & 36.74 & 5.49 & 0.45 & 3 & 30.07 .03 & 152.66 & 1 & 27.08 .03 \\
\hline Phosphate $(\mu \mathrm{M})$ & 6.67 & 1.28 & 0.34 & 3 & 30.12 .02 & 43.46 & 1 & 16.09 .03 \\
\hline $\mathrm{CHLa}\left(\mathrm{mg} \mathrm{m}^{-3}\right)$ & 7.40 & 2.30 & 0.20 & 3 & 30.12 .02 & 90.97 & 1 & 27.08 .03 \\
\hline $\mathrm{FC}\left(\mathrm{cfu} 100 \mathrm{ml}^{-1}\right)$ & 172,017 & 30,567 & 3,000 & 3 & 16.04 .03 & 983,000 & 4 & 30.12 .02 \\
\hline
\end{tabular}

which are compatible with fecal coliform values and with sewage contaminations.

The PCA results of physicochemical and microbiological data (Fig. 2) indicated that station 1

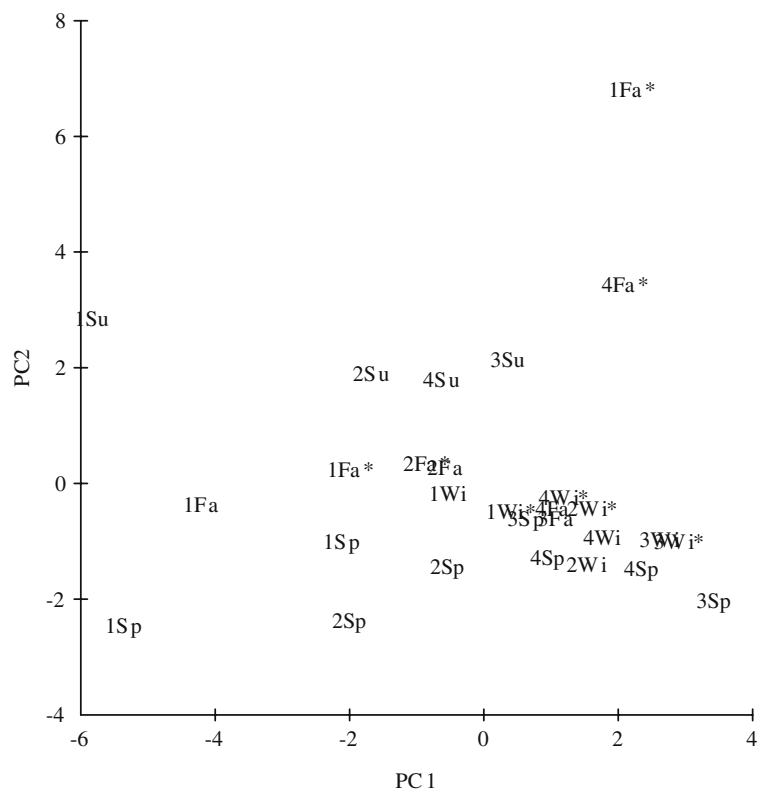

Fig. 2 PCA plot for stations and seasons for the environmental parameters: Temperature, Conductivity, Oxygen Saturation, pH, Turbidity, Total Suspended Solids, COD, $\mathrm{BOD}_{5}, \mathrm{CHLa}, \mathrm{FC}$, Nitrate, Nitrite, Ammonium, and Phosphate. (1-4 sampling stations; asterisk data from 2002; Fa fall; $W i$ winter; $S p$ spring; $S u$ summer) was distinct from remaining stations, in particular during spring and summer, and the same trend occurred for stations 3 and 4 during the fall. The physicochemical and microbiological properties of the latter two stations were similar in the spring and winter period. The correlation of PC1 (eigenvalue 5.43, 33.9\% of total explained variation) with environmental parameters expressing water quality (temperature, conductivity, oxygen saturation, $\mathrm{pH}$, turbidity, total suspended solids, $\mathrm{COD}, \mathrm{BOD}_{5}$, CHLa, FC, nitrate, nitrite, ammonium, and phosphate) showed that the variables more directly associated with contamination (conductivity, FC, and ammonium) were the main responsible for the distribution of the different stations. These parameters strongly separate station 1, which was severely polluted and exhibited a higher concentration of the mentioned parameters. The correlation of PC2 (eigenvalue $3.90,24.4 \%$ of total explained variation) showed that differences in the physicochemical parameters turbidity, total suspended solids, and COD separated samples taken in fall and summer. We believe that the hydrological variation is the key factor for such separation in the diagram.

Physical, chemical, and organic/microbiological parameters were assessed integrally using the WQI (Table 2). Average WQI values are presented in Table 5 and its spatial distribution on Fig. 3. Water quality ranged from polluted to 
badly polluted with the worst values occurring at the lower stations (Tukey HSD Test, $p<0.05$ ). Overall water quality decreased from May 2003, especially in the two lower stations (Fig. 3), resulting into significant temporal variation (ANOVA, $p<0.05)$.

\section{Sediment characterization}

Gravel fractions ( $>2 \mathrm{~mm}$ ) dominated at upper and lower sampling stations, while medium and fine sand fractions ( 0.125 to $0.5 \mathrm{~mm})$ predominated in station 2 samples (Fig. 4). Organic matter contents averaged $3.4 \pm 1.2 \%$ throughout the river and values $>2 \%$ were common (Fig. 5), but no significant differences were found (ANOVA, $p>0.05)$.

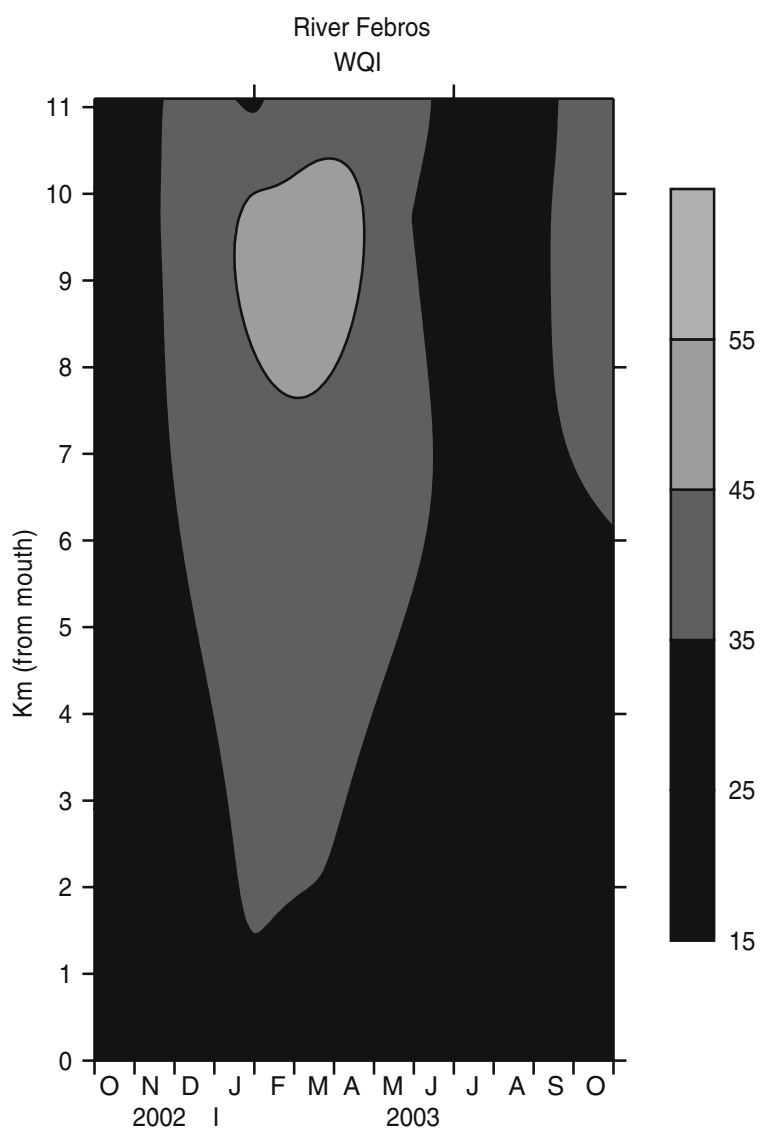

Fig. 3 Spatial distribution of WQI isolines for the river Febros, from October 2002 to October 2003 
Fig. 4 Representation of the average percentages of each substrate type in the four sampling stations of river Febros (1 mouth, 4 upstream)
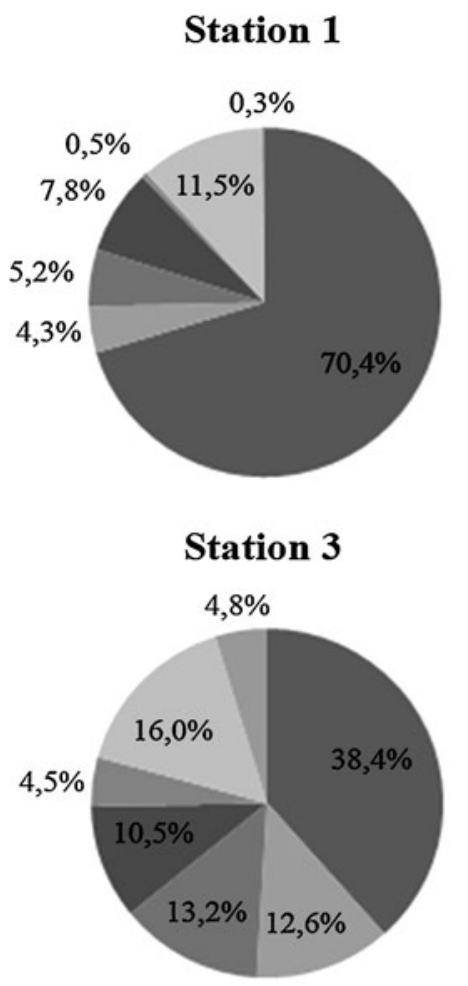

$$
\begin{array}{ll}
\text { a Gravel } & \text { a Very coarse sand } \\
\text { m Fine sand } & \text { = Very fine sand }
\end{array}
$$
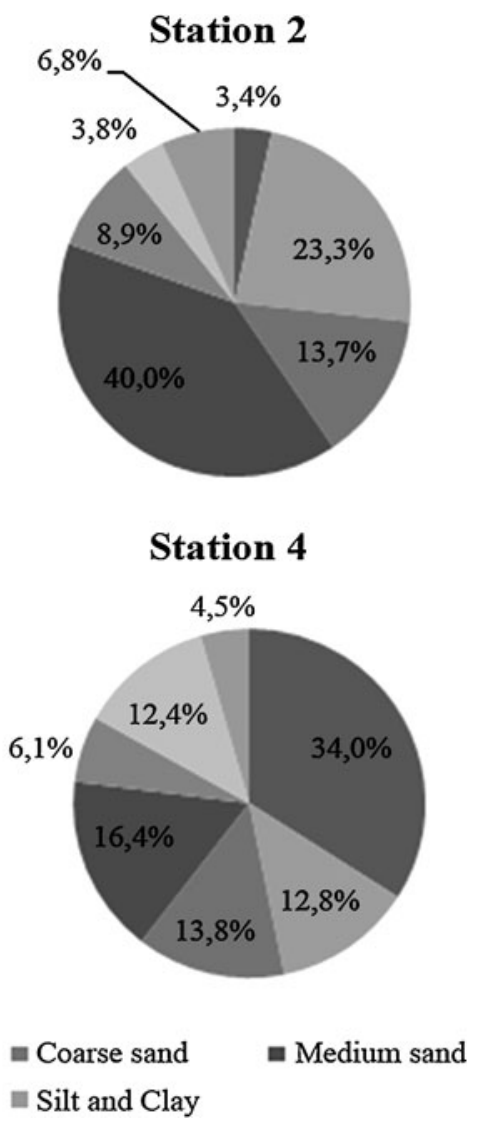

Biological assessment

Benthic macroinvertebrate diversity was low throughout the study, with an average of $\mathrm{H}^{\prime}<1.57$ (Table 6). IBMWP scores were in the range of 16-35 (Table 5), indicating highly contaminated water at all sampling stations. Average ASPT values were also low (Table 6), varying between $2.38 \pm 0.11$ (station 2) and $3.05 \pm 0.34$ (station 3). Values for station 3 indicated higher ecological status than station 4, which is also supported by the EPT index values (Table 6). In fact, besides
Fig. 5 Variation of the organic matter content in the four sampling stations of river Febros ( 1 mouth, 4 upstream)

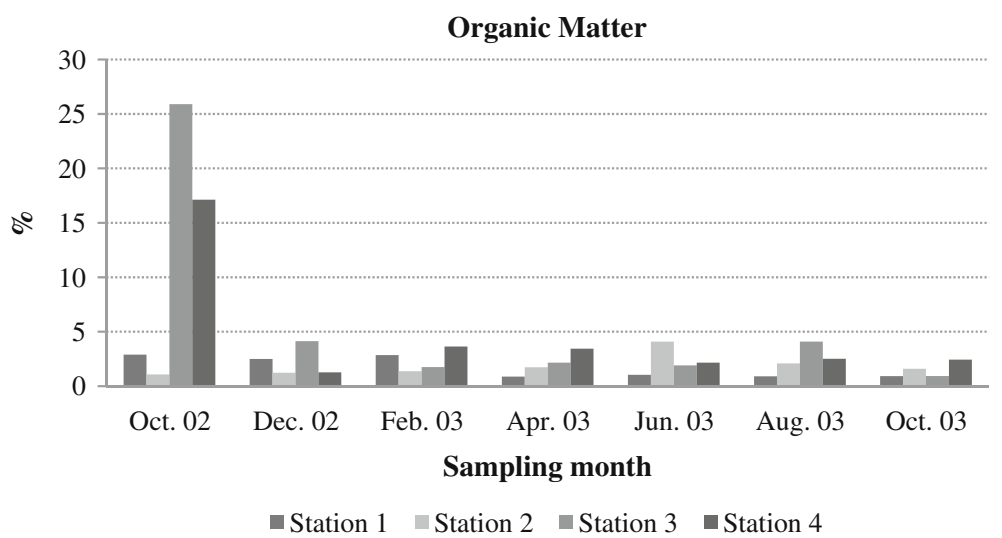


Table 6 Averaged values $( \pm \mathrm{SE})$ for benthic macroinvertebrates diversity $\left(\mathrm{H}^{\prime}\right), \mathrm{ASPT}$, and EPT for the four sampling stations of the river Febros, between October 2002 and October 2003

\begin{tabular}{llll}
\hline $\begin{array}{l}\text { Sampling } \\
\text { station }\end{array}$ & $\begin{array}{l}\text { Macroinvertebrates } \\
\text { diversity }\left(\mathrm{H}^{\prime}\right)\end{array}$ & ASPT & EPT \\
\hline 1 & $1.12 \pm 0.20$ & $2.40 \pm 0.16$ & $0.29 \pm 0.19$ \\
2 & $1.21 \pm 0.14$ & $2.38 \pm 0.11$ & $0.75 \pm 0.48$ \\
3 & $1.06 \pm 0.16$ & $3.05 \pm 0.34$ & $2.86 \pm 0.83$ \\
4 & $1.57 \pm 0.07$ & $2.95 \pm 0.36$ & $2.14 \pm 1.16$ \\
\hline
\end{tabular}

1-mouth, 4-upstream

$A S P T$ average score per taxa, EPT Ephemeroptera + Plecoptera + Trichoptera taxa richness

the slow increase in water quality between stations 3 and 4 (Table 5), the ASPT and EPT values were also higher on station 3 (Table 6). Average percentages of benthic macroinvertebrate groups (Fig. 6) indicate that Annelids and especially Oligochaetes were dominant at downstream sites
( $83 \%$ and $75.7 \%$ for station 1 and 2 , respectively), whereas arthropods were most frequent at sampling site $3(40.2 \%)$ and mollusks at station 4 $(43.3 \%)$.

nMDS results of the macrobenthic faunal distribution (Fig. 7) indicate that communities sampled in the summer surveys were distinct from winter communities; the low stress value indicated good data interpretation. Assemblages are more similar between sites in summertime, due to the higher impact of disturbance that imposes a general lower diversity and global dominance of the most tolerant benthic species.

River corridor and fluvial habitat

The QBR index indicated a downstream decrease in riparian quality (Table 5) ranging from slightly disturbed (QBR 75-80) to strong alteration/bad quality at station 1 (QBR 40).
Fig. 6 Representation of the average percentages of benthic macroinvertebrates groups in the four sampling stations of river Febros ( 1 mouth, 4 upstream)
Station 1

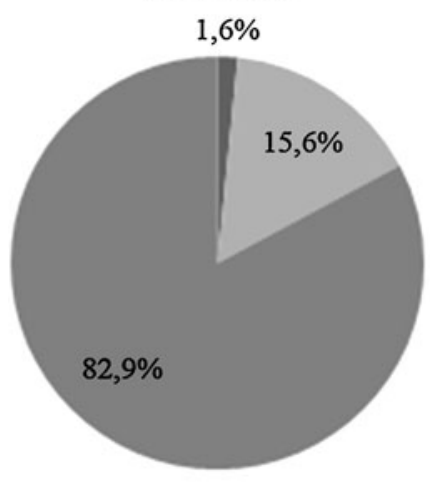

Station 3

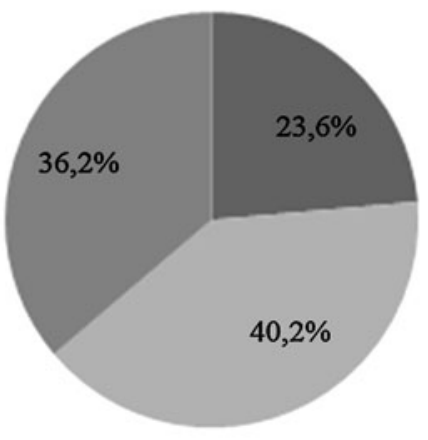

Station 2

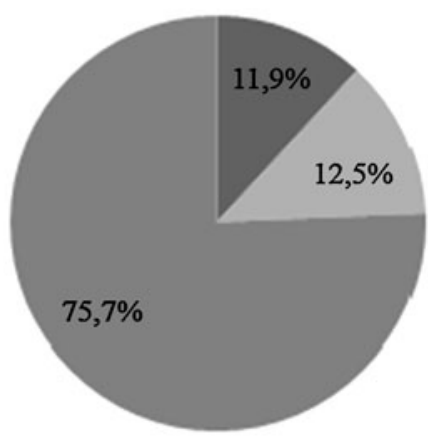

Station 4

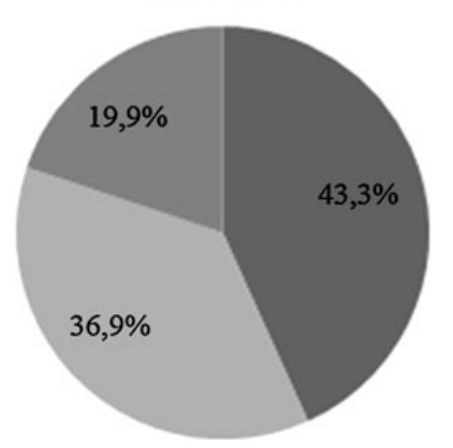

- Mollusca

Arthropoda

Annelidae 


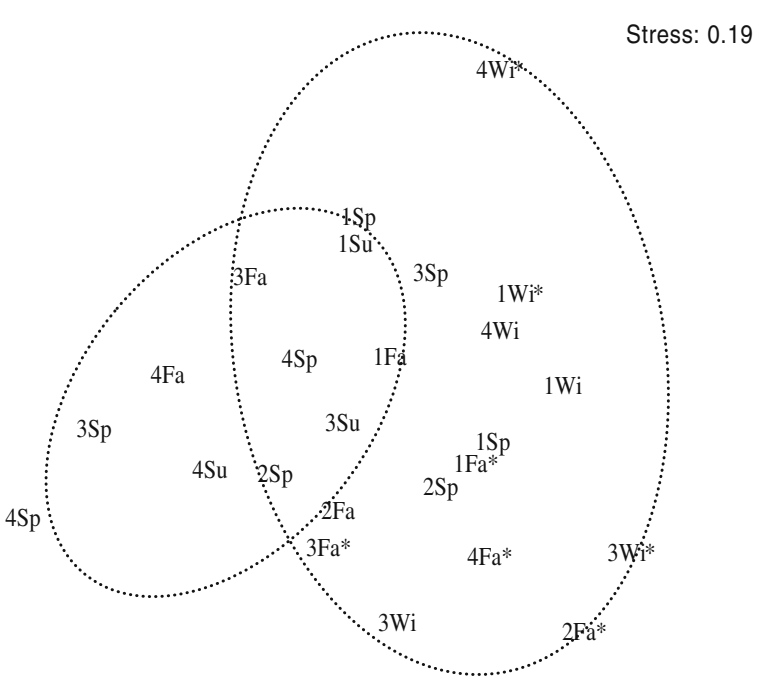

Fig. 7 Ordination of samples in two dimensions using nMDS based on Bray-Curtis similarity matrix of macroinvertebrates families: Ancylidae, Asellidae, Baetidae, Calopterigidae, Ceratopogonidae, Chironomidae, Dugesiidae, Dysticidae, Empididae, Erpobdelidae, Glossiphoniidae, Haliplidae, Helicopsychidae, Hydrobiidae, Hydropsychidae, Leptophlebiidae, Libellulidae, Lumbricidae, Lumbriculidae, Lymnaeidae, Naididae, Philopotamidae, Physidae, Psychodidae, Rhyacophilidae, Simuliidae, Sphaeridae, Tubificidae. (1-4 sampling stations; asterisk data from 2002; Fa fall; Wi winter; $S p$ spring; $S u$ summer)

The ECOSTRIMED index results ranged from mediocre (stations 3 and 4) to very bad (station 1). River Habitat Survey HMSm values ranged from class 1 (station 4) and class 3 (remaining stations; Table 5). Stations located near the river mouth were the most modified (lowest HQAm) while station 4 was considered "semi-natural" state class.

\section{Scaled values}

Scaled values were calculated in order to rank sampling stations based on their physicochemical, microbiological, biological, and habitat characteristics (Table 7). Station 1 had the lowest relative ranking, resulting from the lowest ecological quality, as well as the lowest IBMWP, EPT, QBR, 1/HMSm, and HQAm. Station 2 had the second lowest relative ranking followed by station 3. Station 4 presented the highest relative ranking which is compatible with the highest values of IBMWP, $\mathrm{H}^{\prime}$, QBR and 1/HMSm.

\section{Discussion}

Nutrient increase such as phosphorus, nitrate, ammonium in urban watersheds resulting from wastewater and fertilizer runoff (e.g., Jordan et al. 2003; Kronvang et al. 2005) is well documented (e.g., Paul and Meyer 2001). The high nutrient levels obtained in this study not only indicate continuous input into the river, with more dramatic effects on the lower reaches, which receive treated sewage subject to partial nutrient removal from a WWTP, but also diffuse agricultural input resulting from the application of untreated sewage, manure, and artificial fertilizers. These factors contribute to the temporal and spatial patterns that were detected. Highly eutrophic rivers have longer nutrient uptake lengths than the noncontaminated ones of similar size, due to higher loading

Table 7 Scaled values of the indices used for the characterization of the global state of each river Febros sampling stations between October 2002 and October 2003

\begin{tabular}{|c|c|c|c|c|}
\hline \multirow[t]{2}{*}{ Scaled values $^{\mathrm{a}}$} & \multicolumn{4}{|c|}{ Stations } \\
\hline & 1 & 2 & 3 & 4 \\
\hline \multicolumn{5}{|c|}{$\begin{array}{l}\text { Based on physicochemical and } \\
\text { microbiological parameters }\end{array}$} \\
\hline WQI & 0 & 2.90 & 10 & 7.99 \\
\hline \multicolumn{5}{|c|}{ Based on biological parameters } \\
\hline IBMWP & 0 & 1.67 & 6.11 & 10 \\
\hline $\mathrm{H}^{\prime}$ & 1.18 & 2.94 & 0 & 10 \\
\hline ASPT & 0.30 & 0 & 10 & 8.51 \\
\hline EPT & 0 & 1.79 & 10 & 7.20 \\
\hline \multicolumn{5}{|c|}{ Based on habitat parameters } \\
\hline QBR & 0 & 6.25 & 8.75 & 10 \\
\hline 1/HMSm & 0 & 0.53 & 0.53 & 10 \\
\hline HQAm & 0 & 0.91 & 10 & 9.09 \\
\hline Mean of scaled values & 0.18 & 2.12 & 6.92 & 9.10 \\
\hline Relative ranking $^{\mathrm{b}}$ & 1 & 2 & 3 & 4 \\
\hline
\end{tabular}

1-mouth, 4-upstream

WQI Water Quality Index; IBMWP Iberian Biological Monitoring Working Party Index; $H^{\prime}$ benthic macroinvertebrates diversity; $A S P T$ average score per taxa; $E P T$ Ephemeroptera + Plecoptera + Trichoptera taxa richness; $Q B R$ Riparian Forest Quality index; 1/HMSm inverse of the Habitat Modification Score modified; HQAm Habitat Quality Assessment modified

${ }^{a}$ All values were scaled to $0-10$ using the following formula: Scaled value $=[($ value - minimum $)-($ maximum minimum) $] \times 10$

${ }^{\mathrm{b}}$ The higher the ranking, the less degraded the station relative to the other stations 
and reduced removal efficiency (Paul and Meyer 2001). This is certainly the case of River Febros, since nutrient contents along the river were constantly high together with high bacterial densities, a common phenomenon in watersheds with waste water treatment plants (Paul and Meyer 2001). Fecal Coliform levels were extremely high, indicating heavy sewage contamination, with average values over 86 times higher than the mandatory values for bathing (2,000 cfu $100 \mathrm{ml}^{-1}$, EEC 1976). The results indicate a clear risk to human health as the water was unsuitable for both irrigation and direct contact (Cabral and Marques 2006). Other factors compromising water quality besides agriculture were point sources of pollution of industrial and urban origin, which overloaded the limited self-depuration capacity of the watercourse.

The highest levels of organic matter were observed at the upstream stations, where riparian quality was also highest (higher percentage of forest, and higher QBR values) and leaf litter represents an important local source of organic matter (Udawatta et al. 2002; Webster et al. 1999). Levels of organic matter were lower at station 2 possibly related to the lower levels of forest land use compared to the upper stations. High levels of organic matter were found in sediments (average $>3 \%$ ), although, no seasonal pattern was detected. According to Allan et al. (1997), local conditions (e.g., vegetative cover at a site) determine particulate organic matter input, but landscape features, such as upstream land use, regulate nutrient and sediment delivery. Although few studies have considered the mineralization of organic matter (Harper 1992; Paul and Meyer 2001), macroinvertebrates have an important role in its decomposition and metabolization, thereby contributing to water depuration.

Ecosystem health has an inverse relationship with human impacts resulting in the presence of few tolerant species in very large numbers (Brown 2005; Newman and Medmenham 1992; Novotny et al. 2005). We found very low benthic macroinvertebrates diversity $\left(\mathrm{H}^{\prime}\right)$ with the minimum value occurring at the station with the highest WQI, despite being polluted. The IBMWP, ASPT, and EPT values were low for all sites, with the lowest values occurring downstream; this was also the case for the total number of taxa within the EPT insect groups (EPT index) used to evaluate community balance. Well represented in the benthic community, these taxa represent improved ecological conditions, which was not the case in our study. Oligochaetes are successful colonizers of eutrophic environments, since they have coetaneous breathing (Azrina et al. 2006) and were the dominant macroinvertebrate group near the river mouth, which is in agreement with the lower WQI values. However, station 3 had the greatest percentage of arthropods, mainly chironomids, which also have respiratory adaptations to anaerobic conditions (e.g., anal tubules, haemoglobin; Boué and Chanton 1962; Chinery 1992; Fitter and Manuel 1994; Resh and Rosenberg 1984; Ross et al. 1982). The most dominant groups were Gastropoda and Bivalvia: their presence can be attributed to the highest percentage of organic matter since they are scrapers. Our results clearly show the predominance of tolerant organisms, reflecting the difficulty of using diversity or biotic indices in disturbed environments, since the taxa is reduced to a few groups. There were no evident similarities between the macroinvertebrate families in the four sampling stations, but marked seasonal patterns were observed, despite of the described chemical trends. This is typical of highly polluted streams, since there is a lack of insects, which exhibit life cycles (e.g., voltinism) more dependent on the temperature (Briers and Gee 2004; Collier and Smith 2000; Jacobsen et al. 1997; Petersen et al. 2004).

The surrounding landscape strongly influences aquatic ecosystems and the effect of land use on streams (Walsh et al. 2003) has been well studied. Some authors (e.g., Rogers et al. 2002) indicate habitat degradation as the main driver of ecological impairment rather than chemical pollution. Landscape attributes also provide new insights into the anthropogenic influences on aquatic ecosystems, complementing information provided by traditional indicators (Gergel et al. 2002). Landscape attributes require quantification, arrangement of land cover types, and the physical structure of vegetation on the land surface the shape of patches and their spatial arrangement and connectivity. In this study, both QBR and ECOSTRIMED indices assessed 
all river corridor habitats as poor although there were slight improvements upstream. Similar trends of QBR were obtained by Munné et al. (2003). Values of HQAm (RHS) were lower at downstream stations (1 and 2) than at station 3 , in agreement with the WQI results. Results indicate that the differences in riparian quality were not reflected on a more clear improvement of the benthic fauna. This could be explained by the considerable longitudinal nutrient input by the different pollution sources exceeding the retention or nutrient absorption capacity efficiency of the riparian vegetation (Allan et al. 1997; Mokaya et al. 2004). Urban et al. (2006) pointed out that maintenance and restriction of watershed vegetation corridors in urban landscapes is vital to conserving freshwater biodiversity. Despite seasonal changes in the benthic composition, the chemical and biological quality results were consistently low. The limited capacity of the system to cope with the multiple disturbance factors resulted in permanently reduced diversity and the absence of intolerant species such as stoneflies, caddish flies, mayflies, and shredders. Riparian zones play a multifaceted role in flood mitigation as nutrient buffers, sediment traps, climate regulators and wildlife refuges (e.g., Lyon and Gross 2005). Thus, their alteration can have far-reaching effects on the structure and function of running water ecosystems (Tabacchi et al. 2000; Winterbourn and Townsend 1991). The influence of the vegetation on the geomorphology is also of great importance for flow resistance, maintaining bank stability, sediment storage, bed stability, and stream morphology as well as the aquatic system function (Vogt et al. 2004; Webb and Erskine 2003) and conservation of biodiversity (Lazdinis and Angelstam 2005). The efficacy of riparian galleries in highly enriched streams is always under discussion (Lovell and Sullivan 2006; Lyon and Gross 2005). Nevertheless, all the classifications used in this study (chemical and biological components and riparian corridors) showed how impaired is the studied river, being the small differences obtained among the different indices related to each own's resolution. Yet, the rehabilitation works must be defined at the watershed scale. At the same time, the assessment of the biotic integrity implies the use of holistic approaches, and em- phasizes the need of taking into account all the elements (water, sediment, vegetation, and biota).

Essentially, the integration of the several indices (WQI, IBMWP, H', ASPT, EPT, QBR, HMSm, and HQAm) used in this study, which include the different parameters (physical, chemical, microbiological, biological, and habitat) allows the observation of a decrease in overall quality of the River Febros from the source to the mouth. These results show that is questionable if the improvement of the ecological condition of the river may be achieved only by restoring the physical habitat along the river corridor. In order to improve the ecological status, a global management plan decreasing point and non-point pollution over the entire watershed is required, together with the rehabilitation of the riparian layer and the creation of conditions for settling nutrients and sediments.

\section{Conclusions}

The River Febros watershed is submitted to dramatic changes of soil use and vegetation cover over its length, resulting in disrupted connections between the biotic and abiotic elements. This imposes serious constraints for developing an integrated method to describe ecologically such a disturbed system. Scaled values of multiple indices allowed water and sediment quality characterization, as well as classification of the associated riparian zones and assessment of its biological condition. Although no significant statistical correlations between habitat indices and water quality (chemical and biological) were found, instream ecological conditions decreased downstream. Therefore, differences in riparian quality were not reflected in the benthic fauna, as a result of the very high longitudinal nutrient and organic matter inputs (diffuse sources). Data suggested that low ecological quality of this river is a consequence of the saturation of the reduced buffering capacity of the riparian strip against human impacts. The importance of analysing several components of a disturbed ecosystem to ascertain its overall quality was highlighted, providing a case study for numerous streams along the Atlantic Coast of Europe. 
Acknowledgements This study was funded by the Portuguese Foundation for Science and Technology (FCT), through a fellowship awarded to Liliana Carvalho (SRFH/BD/7073/2001).

The authors thank all who participated in field surveys and laboratorial work (both from ICBAS and Águas de Gaia, E.M.). The authors would like to thank Dr. Samantha Jane Hughes (CITAB, UTAD) for revising the manuscript.

\section{References}

Alba-Tercedor, J., \& Sánchez-Ortega, A. (1988). Un método rápido para evaluar la calidad biológica de las aguas corrientes en el de Helawell (1978). Limnetica, 4, 51-56.

Allan, J. D., Erickson, D. L., \& Fay, J. (1997). The influence of catchment land use on stream integrity across multiple spatial scales. Freshwater Biology, 37, 149-161.

APHA (1992). Standard methods for the examination of the water and wastewater. Washington, DC: American Public Health Association.

Armitage, P. D., Moss, D., Wright, J. F., \& Furse, M. T. (1983). The performance of a new biological water quality score system based on macroinvertebrates over a wide range of unpolluted running-water sites. Water Research, 17, 333-347.

Azrina, M. Z., Yap, C. K., Ismail, A. R., Ismail, A., \& Tan, S. G. (2006). Anthropogenic impacts on the distribution and biodiversity of benthic macroinvertebrates and water quality of the Langat River, Peninsular Malaysia. Ecotoxicology and Environmental Safety, 64, 337-347.

Baer, K. E., \& Pringle, C. M. (2000). In P. J. Boon, B. R. Davies, \& G. E. Petts (Eds.), Global perspectives on river conservation: Science, policy and practice (pp. 381-398). Chichester: Wiley.

Barbour, M. T., Gerritsen, J., Snyder, B. D., \& Stribling, J. B. (1999). Rapid bioassessment protocols for use in strems and wadeable rivers: Periphyton, benthic macroinvertebrates and fish (2nd ed.). EPA 841-B-9-002. U. S. Environmental Protection Agency, Office of Water, Washington, D. C. Assessed 10 May 2004 from http://www.epa.gov/owow/monitoring/ techmon.html.

Bordalo, A. A. (1993). Effects of salinity on bacterioplankton: Field and microcosm experiments. Journal of Applied Bacteriology, 75, 393-398.

Bordalo, A. A., Nilsumranchit, W., \& Chalermwat, K. (2001). Water quality and uses of the Bangpakong River (Eastern Thailand). Water Research, 35, 36353642 .

Bordalo, A. A., Teixeira, R., \& Wiebe, W. J. (2006). A water quality index applied to an international shared river basin: The case of the Douro River. Environmental Management, 38, 910-920.

Boué, H., \& Chanton, R. (1962). Biologie animale (723 pp.). Zoologie I. G. Doin \& C ${ }^{\text {ie. }}$.
Bray, J. R., \& Curtis, J. T. (1957). An ordination of the upland forest communities of southern Wisconsin. Ecology Monographs, 27, 325-349.

Briers, R. A., \& Gee, J. H. R. (2004). Riparian forestry management and adult stream insects. Hydrology and Earth System Sciences, 8, 545-549.

Brown, L. R. (2005). Aquatic assemblages of the highly urbanized Santa Ana river basin, California. American Fisheries Society Symposium, 47, 263-287.

Cabral, J. P., \& Marques, C. (2006). Faecal coliform bacteria in Febros river (Northwest Portugal): Temporal variation, correlation with water parameters, and species identification. Environmental Monitoring and Assessment, 118, 21-36.

Carpenter, J. (1965). The accuracy of the Winkler method for dissolved oxygen. Limnology and Oceanography, 10, 135-140.

Carpenter, S. R., Caraco, N. F., Correll, D. L., Howarth, R. W., Sharpley, A. N., \& Smith, V. H. (1998). Nonpoint pollution of surface waters with phosphorus and nitrogen. Ecological Applications, 8, 559-568.

Carritt, D. E., \& Carpenter, J. H. (1966). Comparison and evaluation of currently employed modifications of the winkler method for determining dissolved oxygen in seawater: A NASCO report. Journal of Marine Research, 24, 286-318.

Chinery, M. (1992). Insects d'Europe. Multiguide nature (pp. 380). Paris: Bordas.

Chovanec, A., Jäger, P., Jungwirth, M., Koller-Kreimel, V., Moog, O., Muhar, S., et al. (2000). The Austrian way of assessing the ecological integrity of running waters: A contribution to the EU water framework directive. Hydrobiologia, 422/423, 445-452.

Clarke, K. R., \& Warwick, R. M. (1994). Change in marine communities. An approach to statistical analysis and interpolation (pp. 144). Plymouth, UK: National Environmental Research Council.

Collier, K. J., \& Smith, B. J. (2000). Interactions of adult stoneflies (Plecoptera) with Riparian Zones I. Effects of air temperature and humidity on longevity. Aquatic Insects, 22, 275-284.

Cortes, R. M. V., Oliveira, S. V., Cabral, D. A., Santos, S., \& Ferreira, T. (2002). Different scales of analysis in classifying streams: From a multimetric towards an integrate system approach. Large Rivers, 13(Suppl. Archiv für Hydrobiologie, 141), 209-224.

Cortes, R. M. V., Varandas, S., Hughes, S. J., \& Ferreira, M. T. (2008). Combining habitat and biological characterization: Ecological validation of the River Habitat Survey. Limnetica, 27, 39-56.

Dale, V. H., Brown, S., Haeuber, R., Hobbs, N. T., Huntly, N., Naiman, R. J., et al. (2000). Ecological principles and guidelines for managing the use of land. Ecological Applications, 10, 639-670.

Davenport, A. J., Gurnell, A. M., \& Armitage, P. D. (2004). Habitat Survey and classification of urban rivers. River Research and Applications, 20, 687-704.

EC (2000). Directive 2000/60/EC of the European Parliament and of the Council of 23 October 2000 establishing a framework for community action in the 
field of water policy. Official Journal of the European Communities, L327, 1-73. (22.12.2000).

EEC (1976). Council directive of 8 December 1975 concerning the quality of bathing water (76/160/EEC). Official Journal of the European Community, 1-7. (05.02.1976).

Fitter, R., \& Manuel, R. (1994). Lakes, rivers, streams \& ponds of Britain \& North-West Europe. Collins photo guide (p. 382). Harper Collins Publishers.

Geraldes, A. M., \& Boavida, M. J. (2003). Distinct age and landscape influence on two reservoirs under the same climate. Hydrobiologia, 504, 277-288.

Gergel, S. E., Turner, M. G., Millar, J. R., Melack, J. M., \& Stanley, E. H. (2002). Landscape indicators of human impacts to riverine systems. Aquatic Sciences, 64, 118128.

Grasshoff, K., Ehrhardt, M., \& Kremling, K. (1983). Methods of seawater analysis. Second revised and extended edition (p. 419). Weinheim: Verlag Chemie.

Harper, D. (1992). Eutrophication of freshwaters. Principles, problems and restoration (p. 327). New York: Chapmann \& Hall.

Harper, D. M., Ebrahimnezhad, M., Taylor, E., Dickinson, S., Decamp, O., Vernier, G., et al. (1999). A catchment-scale approach to the physical restoration of lowland UK rivers. Aquatic Conservation: Marine and Freshwater Ecosystems, 9, 141-157.

House, M. A. (1989). A water quality index for river management. Journal of the Institute of Water \& Environmental Management, 3, 336-344.

House, M. A., \& Ellis, J. B. (1987). The development of water quality indices for operational management. Water Science and Technology, 19, 145-154.

Jacobsen, D., Schultz, R., \& Encalada, A. (1997). Structure and diversity of stream invertebrate assemblages: The influence of temperature with altitude and latitude. Freshwater Biology, 38, 247-261.

Jones, M. N. (1984). Nitrate reduction by shaking with cadmium: Alternative to cadmium columns. Water Research, 18, 643-646.

Jordan, T. E., Whigham, D. F., Hofmockel, K. H., \& Pittek, M. A. (2003). Wetlands and aquatic processes. Nutrient and sediment removal by a restored wetland receiving agricultural runoff. Journal of Environmental Quality, 32, 1534-1547.

Karr, J. R., Fausch, K. D., Angermeier, P. L., Yant, P. R., \& Schlosser, I. J. (1986). Assessing biological integrity in running waters: A method and its rationale. III natural history survey (p. 28). Urbana: Illinois Natural History.

Kronvang, B., Bechamnn, M., Lundekvam, H., Behrendt, H., Rubæk, G. H., Schoumans, O. F., et al. (2005). Phosphorous losses from agricultural areas in river basins: Effects and uncertainties of targeted mitigation measures. Journal of Environmental Quality, 34, 21292144.

Lazdinis, M., \& Angelstam, P. (2005). Functionality of riparian forest ecotones in the context of former Soviet Union and Swedish forest management histories. Forest Policy and Economics, 7, 321-332.

Lovell, S. T., \& Sullivan, W. C. (2006). Environmental benefits of conservation buffers in the United
States: Evidence, promise, and open questions. Agriculture, Ecosystems and Environment, 112, 249260.

Lyon, J., \& Gross, N. M. (2005). Patterns of plant diversity and plant-environmental relationships across three riparian corridors. Forest Ecology and Management, 204, 267-278.

Maddock, I. (1999). The importance of physical habitat assessment for evaluating river health. Freshwater Biology, 41, 373-391.

Mainstone, C. P., \& Parr, W. (2002). Phosphorous in riversecology and management. The Science of The Total Environment, 282/283, 25-47.

Mander, Ü., Kuusemets, V., \& Ivask, M. (1995). Nutrient dynamics of riparian ecotones: A case study from the Porijõgi River catchment, Estonia. Landscape and Urban Planning, 31, 333-348.

Mokaya, S. K., Mathooko, J. M., \& Leichtfried, M. (2004). Influence of anthropogenic activities on water quality of a tropical stream ecosystem. African Journal of Ecology, 42, 281-288.

Munné, A., Sola, C., \& Prat, N. (1998). QBR: Un índice rápido para la evaluación de la calidad de los bosques de ribera. Tecnologia Del Agua, 175, 20-37.

Munné, A., Prat, N., Solà, F., Bonada, N., \& Rieradevall, M. (2003). A simple field method for assessing the ecological quality of riparian habitat in rivers and streams: QBR index. Aquatic Conservation: Marine and Freshwater Ecosystems, 13, 147-163.

Naiman, R. J., \& Décamps, H. (1997). The ecology of interfaces: Riparian zones. Annual Review of Ecology and Systematics, 28, 621-658.

Naiman, R. J., Magnuson, J. J., McKnight, D. M., \& Stanford, J. A. (1995). The freshwater imperative: $A$ research agenda (p. 165). Washington, DC: Island Press.

Newman, P. J., \& Medmenham, W. R. (1992). Assessment of river water quality in UK. Tribune de l'eau, 555, 8-17.

Novotny, V., Bartošová, A., O’Reilly, N., \& Ehlinger, T. (2005). Unlocking the relationship of biotic integrity of impaired waters to anthropogenic stresses. Water Research, 39, 184-198.

Palmer, M. A., Glenn, E. M., Bockstaed, N. E., Brooks, S., Pizzuto, J. E., Wiegand, C., et al. (2002). The ecological consequences of changing land use for running waters, with a case study of urbanizing watersheds in Maryland. Yale Bulletin of Environmental Science, 107, 85-113.

Parsons, T. R., Maita, Y., \& Lalli, C. M. (1984). A manual of chemical and biological methods for seawater analysis (pp. 101-112). Elmsford: Pergamon.

Paul, M. J., \& Meyer, J. L. (2001). Streams in the urban landscape. Annual Review of Ecology and Systematics, 32, 333-365.

Petersen, I., Masters, Z., Hildrew, A. G., \& Ormerod, S. J. (2004). Dispersal of adult aquatic insects in catchments of differing land use. Journal of Applied Ecology, 41, 934-950.

Piégay, H., \& Landon, N. (1997). Promoting ecological management of riparian forests on the Drôme River, 
France. Aquatic Conservation: Marine and Freshwater Ecosystems, 7, 287-304.

Prat, N., Munné, A., Rieradevall, M., Solà, C., \& Bonada, N. (2000). ECOSTRIMED. Protocol per determinar l'estat ecològic dels rius mediterranis. Diputació de Barcelona. Área de Medi Ambient (Estudis de la Qualitat Ecològica dels Rius, 8) (p. 94).

Raven, P. J., Holmes, N. T. H., Dawson, F. H., \& Everard, M. (1998). Quality assessment using River Habitat Survey data. Aquatic Conservation: Marine and Freshwater Ecosystems, 8, 477-499.

Resh, V. H., \& Rosenberg, D. M. (1984). The ecology of aquatic insects (p. 625). New York: Praeger.

Reynoldson, T. B., Norris, R. H., Resh, V. H., Day, K. E., \& Rosenberg, D. M. (1997). The reference condition: A comparison of multimetric approaches to assess waterquality impairment using benthic macroinvertebrates. Journal of the North American Benthological Society, $16,833-852$.

Rico, E., Ralla, A., Sevillano, M. A., \& Arretxe, M. L. (1992). Compairison of several biological índices based on river macroinvertebrates benthic community for the assessment of running water quality. Annales de Limnologie, 28, 147-156.

Robertson, A. I., \& Rowling, R. W. (2000). Effects of livestock on Riparian Zone vegetation in an Australian Dryland river. Regulated Rivers: Research \& Management, 16, 527-541.

Rogers, C. E., Brabander, D. J., Barbour, M. T., \& Hemond, H. F. (2002). Use of physical, chemical, and biological indices to assess impacts of contaminants and physical habitat alteration in urban streams. Environmental Toxicology and Chemistry, 21, 11561167.

Ross, H. H., Ross, C. A., \& Ross, J. R. P. (1982). A textbook of entomology (p. 666). Hoboken: Wiley.

SCOR-UNESCO (1966). Determination of photosynthetic pigments in seawater. Report of the SCOR-UNESCO Working Group 17. In UNESCO (Ed.), Monographs on oceanographic methodology (pp. 11-18). Paris: UNESCO.

SDD (1976). Development of a water quality index (p. 72). Edinburgh: Scottish Development Department, Report ARD3.

Shannon, C. E., \& Weaver, W. (1963). The mathematical theory of communications (p. 125). Urbana: University of Illinois Press.

Sweeting, R. A. (1994). In P. Calow \& G. E. Petts (Eds.), The rivers handbook (2nd Vol., pp. 23-32). Oxford: Blackwell.

Tabacchi, E., Lambs, L., Guilloy, H., Planty-Tabacchi, A. M., Muller, E., \& Décamps, H. (2000). Impacts of riparian vegetation on hydrological processes. Hydrological Processes, 14, 2959-2976.

Tachet, H., Boumaud, M., \& Richoux, P. H. (1994). Introduction à l'étude des macroinvertebres des eaux douces (Systématique élémentaire et aperçu écologique) ( $4^{e}$ ed.). Université Lyon I et Association Française de Limnologie.

Thoms, M. C., \& Sheldon, F. (2000). Lowland rivers: An Australian introduction. Regulated Rivers: Research and Management, 16, 375-383.

Tickner, D., Armitage, P. D., Bickerton, M. A., \& Hall, K. A. (2000). Assessing stream quality using information on mesohabitat distribution and character. Aquatic Conservation: Marine and Freshwater Ecosystems, 10, 179-196.

Udawatta, R. P., Krstansky, J. J., Henderson, G. S., \& Garrett, H. E. (2002). Agroforestry practices, runoff, and nutrient loss: A paired watershed comparison. Journal of Environmental Quality, 31, 1214-1225.

Urban, M. C., Skelly, D. K., Burchsted, D., Price, W., \& Lowry, S. (2006). Stream communities across a ruralurban landscape gradient. Diversity and Distributions, 12, 337-350.

Vogt, J., Puumalainen, J., Kennedy, P., \& Folving, S. (2004). Integrating information on river networks, catchments and major forest types: Towards the characterisation and analysis of European landscapes. Landscape and Urban Planning, 67, 27-41.

Vought, L. B.-M., Pinay, G., Fuglsang, A., \& Ruffinoni, C. (1995). Structure and function of buffer strips from a water quality perspective in agricultural landscapes. Landscape and Urban Planning, 31, 323-331.

Walsh, S. E., Soranno, P. A., \& Rutledge, D. T. (2003). Research. Lakes, Wetlands and streams as predictors of land use/cover distribution. Environmental Management, 31, 198-214.

Webb, A. A., \& Erskine, W. D. (2003). A practical scientific approach to riparian vegetation rehabilitation in Australia. Journal of Environmental Management, 68, 329-341.

Webster, J. R., Benfield, E. F., Ehrman, T. P., Schaeffer, M. A., Tank, J. L., Hutchens, J. J., et al. (1999). What happens to allochthonous material that falls into streams? A synthesis of new and published information from Coweeta. Freshwater Biology, 41, 687-705.

Williams, J. E., Wood, C. A., \& Dombeck, M. P. (1997). Watershed restoration: Principles and practices (p. 561). Bethesda, Maryland: American Fisheries Society.

Winterbourn, M. J., \& Townsend, C. R. (1991). In R. S. K. Barnes \& K. H. Mann (Eds.), Fundaments of aquatic ecology (2nd ed., pp. 230-242). London: Blackwell. 